\title{
CHALLENGES FACED BY THE ROMANIAN LAND FORCES REGARDING TRAINING FOR THE OPERATIONS IN THE URBAN ENVIRONMENT
}

\author{
Daniel SOLESCU \\ "Nicolae Bălcescu” Land Forces Academy, Sibiu, Romania \\ solescu.daniel@armyacademy.ro
}

\begin{abstract}
The topic addressed in this article is a current one and modern armies discuss it a lot and many analyses and comments can be made. In the article, the author presents the general framework of operations in the urban environment and starting from the operational requirements mandatory to conduct such operations he analyzes the prospects that such operations have in future military operations and proposes directions for action necessary for the effective training of the subunits within the Romanian Land Forces.
\end{abstract}

KEYWORDS: urban operations, doctrine, training

\section{Introduction}

Today we live in a global environment increasingly full of technological inventions and innovations, of fast social and demographic change, and where international security is being challenged by an increasingly belligerent Russia and the display of China's economic and military power.

Terrestrial military actions are on the verge of fundamental change. The nature of these actions - how and where to fight and with what weapons and tactics - will undergo fundamental, profound and significant changes. In order to meet future military challenges, NATO forces must be prepared to engage in cyber wars, operate without satellite-based communications and navigation, but above all, be able to fight in a complex urban setting.
We believe that these forces must adapt quickly by acquiring new military technologies, throughthe increasingly complex training of fighters and by training future military leaders who can act on future non-linear battlefields, without having reliable radio links between subunits or with higher echelons, but able to make correct decisions under uncertain and risky situations.

First, our study proposes our own vision of the concept of operations in the urban environment from the general perspective of the operations of the Land Forces. The conceptual delimitation of these specific operations, the analysis of the way of action of forces in an extreme hostile environment such as cities or localities, becomes relevant topics of knowledge for future military operations. 
The study aims to demonstrate that, in a future conflict, in which there is a wide range of military missions, it is necessary to study the military actions that can be carried out in the urban environment and present the directions of action regarding training and equipping the infantry subunits within Land Forces to successfully manage these types of operations.

\section{Conceptual Delimitations}

From ancient times the military strategist Sun Tzu warned that "the worst policy is to attack cities. Attack cities only when there is no alternative" (Tzu, 1982, p. 67). However, alongside Sun Tzu's maxim, there is another, equally revered in military circles, adapted from Carl Von Clausewitz, who argues that at the strategic level, the following can be considered as possible centers of gravity: "an economic resource or a key locality; a strategic transport capacity; vital parts of the national territory." (Tofan, Mateescu \& Brumă, 2003, p. 21).

In the current war, military forces prefer not to fight in the cities for good reasons. With endless enemy locations, vertical and underground closed areas and spaces, with a massive number of civilians, most of them children or seniors who may be injured or killed, with stressful situations of operational requirements, it is no wonder that urban battles in the past have been described as a battle in hell.

In the future, it will be difficult for military formations to hide on battlefields flooded with sensors, which means that survival might depend on having smaller and more mobile forces, and military actions will move into dense urban areas with multiple robotic weapons and a large civilian population in the midst of fighting, a situation that makes the enemy extremely elusive and combines conventional warfare with actions of terrorism and guerrilla.

This requires significant changes in current methods of thinking, training and fighting. Army operations in complex and densely populated urban lands are the hardest and bloodiest form of combat and will become the norm, not the exception, in the future.

The Land Forces need new capabilities so that they can work in urban operations. Improvements in intelligence and reconnaissance systems are important for identifying targets in a dense and confusing urban environment, and combat forces will need to be able to operate independently for long periods of time and will need long-range precision weapons. They will also have to strengthen their electronic systems to defend themselves against cyber and electronic warfare attacks or, worse, be prepared to take action without them.

It is possible that logistic supply lines be largely made up of autonomous systems, such as robots and remotely controlled convoys, to reduce the risk of loss among fighters, and "the ability of units to produce or purify their own water and to make their own spare parts with $3 D$ printing can become a necessity" (Milley, 2017).

Future wars in the urban environment will no longer include the comfort and stability that exists today in well-equipped military bases located in areas where stability and support military actions are taking place, and the lives of soldiers will almost certainly be extremely austere. Soldiers will also need to be more independent and imaginative, capable of intuiting the reality of the battlefield and even being independent in the circumstances when they do not have direct connection and support from the upper echelon in order to successfully carry out their missions.

\section{Courses of Action}

Since 2007, the motto of the training center, within the Land Forces, is "Train yourself today, as you fight tomorrow!" (Ciolponea, 2017, p. 92), meant to ensure that they will develop and 
execute a tough and realistic training. As long as we prepare as we fight, no soldier should face a situation or environment in battle for the first time.

Unfortunately, this principle is occasionally ignored. Despite the history and global trends of urbanization, the Land Forces are not adequately trained for operations in urban areas. An approach aimed at solving our lack of expertise should include three areas of effort:

a) Defining and developing the concept of urban operations in an official doctrine;

b) Designing and building a training center of a battalion level specifically dedicated to training fighters and subunits in the skills they need to combat and win a fight in the urban environment;

c) Developing a specialized Kit designed for military actions in urban areas.

Doing this together with several types of forces involved, has the advantages of using more resources and experience.

a) Defining and developing the concept of urban operations in an official doctrine

Recently, the US military replaced the term "urban military operations" with "urban operations," explaining that this new term, unlike the old one, assumes that urbanized land is populated and that population must be a major concern. The concept of urban operations represents not only the need to eliminate enemy forces, but also the presence and inevitable interaction with civilians in the urban environment.

In the particularly complex conditions of the urban environment we need a new way of approaching the fight, but the Land Forces has no doctrine developed for this type of military actions, namely the fight in the urban environment and no comprehensive set of TTPs (tactics, techniques and procedures).
Land Forces specialists should consider the major implications from a tactical point of view, the advantages and disadvantages of conducting the whole range of urban military operations (especially offensive and defensive) and why not, even the fighting of resistance in towns.

It is necessary to set up a committee of experts, officers and non-commissioned officers to collect and compile all available information on the history of urban operations and to be responsible for the creation and further development of this specific doctrine taking into account that urban warfare is not new.

\section{b) Designing and building a training center of a battalion level}

The biggest disruptive factor limiting the development of skills in the field of urban warfare is the lack of special polygons for the realistic training of combat skills and the acquisition of specific TTPs.

Most of the training exercises for operations in the urban environment that the subunits of the Land Forces perform focus especially on assaulting a small building and clearing the rooms in teams of 2,3 or 4 soldiers. The training is often performed by improvising a room with panels to represent the walls or even worse, with a simple white-red band.

We believe that it is time for this to change, and after defining and elaborating the doctrine of urban warfare, an Urban Operations Training Center must be set up to prepare soldiers to fight and survive in this specific environment and at the same time to offer courses built around the elaborated doctrine. This would allow financial resources to be invested in one place, rather than wasted on inadequate facilities, within each unit.

Training within this center should not be limited to the formation of individual skills; it should also be able to train entire subunits. Together, individual and subunit 
training will achieve cohesion and increase the subunit's fighting power.

This training center should simulate all the attributes of urban expansion, an urban center, buildings with multiple floors, roads, alleys, parking areas, underground channels and municipal offices. The site should also support the integration of tanks and of other means of fire, protected by mobile means with infantry forces, which proved to be a necessity in urban warfare.

There are voices who argue that virtual simulations can help compensate for the lack of resources needed to prepare soldiers and subunits for combat in urban areas. However, even if simulation technology improves rapidly and steadily, it will never be a complete substitute for realistic training. Virtual training is a first step in the process of training skills with low costs, but soldiers will still need to use war ammunition, know how to efficiently use the field in which they operate and endure hardships during real training in order to train thoroughly for combat actions. Only a training center with realistic environmental characteristics can best train soldiers and subunits to successfully meet the challenges posed by urban areas.

The training component of the Training Center should be able to support units up to battalion level, the basic maneuvering unit of the army. Facilities, observers / controllers and civilians should be allocated to support complex exercises.

The educational component would be a set of progressive and sequential courses, where soldiers would begin with the training of individual and collective skills to shoot, move and communicate in the urban environment. Then, in some STXs, they will be introduced to an environment full of "civilians." They would learn to live, survive and carry out offensive and defensive operations within small subunits. The culmination of the training will be the execution of 2 LFXs with the group to challenge the soldiers to use the urban facilities in attack and defense.

In order to build this center, we can take as an example the experience of Israel and Germany. Thus, the Urban Warfare Training Center of the Israeli Defense Forces, located on the Tze'elim Army base, built in 2005 with the assistance of the United States at a cost of 45 million dollars, provides an example of what is possible and offers an impressive demonstration of seriousness and commitment to training for urban warfare. Nicknamed "Baladia" (Arabic for "city"), it is a 7.4-square-mile training center used to train soldiers in urban warfare techniques and consists of a Middle Eastern-style imitation with several historic buildings. It has been used to train various military organizations, including the US military and UN security forces. The project was developed in response to the need for greater training in the urban war among the IDF, following the conflict during the Second Intifada (Opall-Rome, 2007).

The German army has started the construction of one of the largest and most modern urban training centers in the world scheduled for completion at the end of 2020 , and the value of the investment is estimated at 100 million euros. Named SCHNÖGGERSBURG, it will include an industrial area, an old and a new town, slums, tall buildings, an airport, a railway and metro station, as well as an artificial river and bridges. In total, $16 \mathrm{~km}$ of roads are being built, from pedestrian alleys to four-lane urban highways, and urban markets of various sizes, where even a large number of people can gather, are scattered throughout the city. As there is no natural water on the land, a riverbed has been set up for an artificial river called EISER, which is $22 \mathrm{~m}$ wide. Five mobile bridges cross the EISER River, with a removable middle section to carry out demolition missions. Underground tunnels connect 
three underground subway stations; and the sewerage system, which has a length of $650 \mathrm{~m}$, reproduces the three-dimensional character of the urban space. The ground facilities include a $1,500 \mathrm{~m}$ railway station with junctions, as well as a functional water installation and a power plant. In total, 180 tall buildings are being built, mostly without interiors. Twenty buildings are structurally strengthened to allow the helicopter to land. A church, a synagogue and a mosque are also being built (Grossman, 2015).

Of course, the amount of money invested by the two countries is very large for the budget of the Romanian Land Forces. Therefore, we consider that it is beneficial to build this center using a location where there was a military unit. This allows the construction of this training center with a minimum of expense.

\section{c) Developing a specialized Kit designed for military actions in urban areas}

Urban operations create specific challenges for infantry subunits, as they have to deal with obstacles and dangers that are not present in other combat zones. Infantry subunits must make breaches, break into buildings, clear all rooms in the building and then cross the street and the open spaces in an urban area.

In order to increase the effectiveness of the subunit and to reduce individual risks, fighters must use special equipment, adapted for the use in the urban environment. When the SOP for the urban operations kit or package is developed, the LCEM and the tactical SOP of the respective subunit must be taken into account. According to the author, this package should contain the following categories of equipment:
1) Sapper tools (axes, hammers, wood and metal saws, shovels, spades, pickaxes, nails and screws of different sizes, pliers for cutting padlocks, crowbars, sledge-hammers, hanging hooks).

2) Items for climbing walls (easy stairs $-3 \times 11$ steps, climbing rope, rope, cat claw, climbing harness, etc.).

3) Items used for signaling or marking (colored chalk, sprays of different colors, chemical lights of different colors, stroboscopes in IR, mirrors for signaling, beacons for signaling, tactical flashlights, marking tape with a length of $100 \mathrm{~m}$, marking squares according to SOP, double sided adhesive tape).

By making this kit, subunit commanders can create an effective training program, also following the correct storage, use and inspection of all component items.

\section{Conclusions}

In the future, the Romanian Land Forces will carry out military actions in cities and it is time to commit to preparing soldiers for this environment. To do this, it needs a training center that gives soldiers the opportunity to develop the necessary skills and abilities, to feel the stress of urban combat and to mentally prepare to operate in the toughest combat space. Without a specialized training unit, making decisions to develop new ways or tools to approach military operations in cities is almost impossible.

The training center will become the proponent of the doctrine of urban operations and will serve to implement tactical innovations and the lessons learned on the battlefields of yesterday and today. At the same time, it will provide a place to test and experiment the specific weapons and equipment in order to prepare the subunits for the urban challenges that a wait on the battlefield of tomorrow. 


\section{REFERENCES}

Ciolponea, C.-A. (2017). Instruieşte-te astăzi, aşa cum vei lupta mâine!. Revista Academiei Forţelor Terestre, nr. 1, 92, Sibiu: Editura Academiei Forțelor Terestre "Nicolae Bălcescu".

Grossman, E. (2015). The German Army and Urban Operations, available at: https://militarysimulation.training, accessed on 23 March 2020.

Milley, M. (2017). Annual Report. Association of the U.S. Army.

Opall-Rome, B. (2007). Marines to train at new Israeli combat center. Marine Corps Times.

Tofan, V., Mateescu, Gh., \& Brumă, M. (2003). Conceptul de centru de greutate vulnerabilităţi majore, instrument de lucru pentru stabilirea obiectivelor şi planificarea operaţiei. Revista Academiei Forţelor Terestre, nr. 2, 21-26, Sibiu: Editura Academiei Forțelor Terestre "Nicolae Bălcescu".

Tzu, S. (1982). Arta Războiului. București: Editura Militară. 